\title{
Monetary Integration in Europe in the Function of Fostering International Business
}

\author{
Srđan Šapić, Srđan Furtula \\ Faculty of Economics, University of Kragujevac, Serbia
}

\begin{abstract}
Through joining the European Economic and Monetary Union a heterogeneous influence of member states cannot be avoided but all countries follow the logic of the economic benefits of unification. Besides reducing transaction costs, greater transparency in prices and the elimination of the uncertainty of exchange rate fluctuations, there is a great impact of open borders on increasing trade between member states. Therefore in this article we will analyze the Andrew Rose effect which estimated that countries with same currency trade over three times as much with each other as countries with different currencies. Through objective and systematic analysis we well conclude that the positive effect of monetary integration on increasing of international trade should be carried out in absolute and relative terms.
\end{abstract}

Keywords: monetary integration, European Economic and Monetary Union, international trade, international business

JEL classification: F150

\section{Introduction}

For various political and economic reasons, the countries can join together and form monetary union. The need to create some form of universal payment dates back to ancient times. In the past, monetary arrangements differ in terms of currency, the functions and organization of the central bank and the degree of political integration. Although they applied different models of monetary integration, it is obvious that the monetary union was often the result of political union and compromise. In contrast, the Economic and Monetary Union, which was formed in 1999 with the single European Central Bank and a single currency, is a kind of experiment, because it is formed without political unification. Will the state with monetary unification achieve the expected benefits of reducing transaction costs of exchange, greater price transparency, elimination of the uncertainty of exchange rate fluctuations, reducing the balance of payments deficit, greater macroeconomic stability, etc., depends on several factors, primarily, of the methods for measuring the economic benefits of unification because they are very difficult to quantify.

The issue of success of monetary integration in economic theory is viewed in the theory of optimal currency areas, which specifies the conditions under which monetary policy can be optimal and long-lasting. Monetary integration in the world is more complicated than conclusions of Robert Mundell and his too simplified model of optimal currency areas, "Mundell,1961", due to lack of Mundell research because Mundell considered the model of unification only two states and excluded the mobility of capital (in the '60s of the last century, capital mobility was limited), "Kennen, Meade, 2008". If states do not meet the criteria of the model of optimal currency area ex ante, that does not mean they will not achieve these criteria ex post, because it is possible that with strong political will and institutions and stable 
macroeconomic policy the countries later realize that optimal currency area. Economic theory clearly indicates that in a monetary union it comes to increasing trade and international business between Member States. Increasing trade among Member States, which form a monetary union, is the result which is realized due to the benefits of monetary integration. In order to increase trade between countries, it is neccessary to reduce the transaction costs of exchange, to increase price transparency and to eliminate the uncertainty of exchange rate fluctuations.

When considering the impact of EMU on increasing trade of Member States, it is necessary to analyze Andrew Rose affect, "Rose, 2000". It's estimated that countries with same currency trade over three times as much with each other as countries with different currencies, which will be the subject of this research.

\section{The impact of monetary integration on the increase of international trade}

Since 1998, internal trade EMU i.e. trade between the EMU countries was increasing. The value of exports and imports of goods within the Eurozone increased from $26 \%$ of GDP in 1998, a year before the introduction of the euro on 33\% of GDP in 2007. Trade in services during the same period increased from $5 \%$ to $7 \%$ of GDP. In 2007, trade between Member States accounted for $50 \%$ of the total trade of the EMU (ECB, 2010) Is there an impact of EMU on increasing trade and whether the global financial crisis has affected trade can be seen from Table 1 below.

Table 1

The Share of Imports of the EMU Countries in Total EU Imports, in percentage

\begin{tabular}{|c|c|c|c|c|c|c|c|c|c|c|}
\hline GEO/TIME & 2005 & 2006 & 2007 & 2008 & 2009 & 2010 & 2011 & 2012 & 2013 & 2014 \\
\hline Belgium & 6.0 & 5.9 & 6.1 & 6.0 & 6.1 & 5.9 & 6.3 & 6.2 & 6.8 & 7.0 \\
\hline Bulgaria & 0.4 & 0.4 & 0.6 & 0.7 & 0.5 & 0.5 & 0.5 & 0.6 & 0.6 & 0.6 \\
\hline Czech Republic & 1.0 & 1.1 & 1.2 & 1.4 & 1.3 & 1.6 & 1.6 & 1.5 & 1.5 & 1.6 \\
\hline Denmark & 1.5 & 1.4 & 1.3 & 1.3 & 1.4 & 1.2 & 1.2 & 1.2 & 1.3 & 1.4 \\
\hline Germany & 18.7 & 19.1 & 18.8 & 18.4 & 19.0 & 19.1 & 19.0 & 18.5 & 18.9 & 18.7 \\
\hline Estonia & 0.2 & 0.2 & 0.2 & 0.1 & 0.1 & 0.1 & 0.2 & 0.2 & 0.1 & 0.1 \\
\hline Ireland & 1.5 & 1.3 & 1.3 & 1.1 & 1.3 & 1.0 & 0.8 & 0.9 & 0.9 & 1.0 \\
\hline Greece & 1.5 & 1.6 & 1.7 & 1.8 & 1.8 & 1.6 & 1.4 & 1.5 & 1.5 & 1.5 \\
\hline Spain & 7.0 & 7.3 & 7.3 & 7.3 & 6.4 & 6.6 & 6.7 & 6.7 & 6.8 & 6.9 \\
\hline France & 11.1 & 9.7 & 9.7 & 9.8 & 10.0 & 9.5 & 9.8 & 9.6 & 9.8 & 9.6 \\
\hline Croatia & 0.4 & 0.4 & 0.5 & 0.5 & 0.5 & 0.4 & 0.4 & 0.3 & 0.3 & 0.2 \\
\hline Italy & 10.5 & 10.8 & 10.8 & 10.8 & 10.1 & 10.7 & 10.7 & 9.9 & 9.5 & 9.1 \\
\hline Cyprus & 0.1 & 0.1 & 0.1 & 0.1 & 0.1 & 0.1 & 0.1 & 0.1 & 0.1 & 0.1 \\
\hline Latvia & 0.1 & 0.2 & 0.2 & 0.2 & 0.1 & 0.1 & 0.2 & 0.2 & 0.2 & 0.2 \\
\hline Lithuania & 0.4 & 0.4 & 0.4 & 0.6 & 0.4 & 0.5 & 0.6 & 0.6 & 0.6 & 0.6 \\
\hline Luxembourg & 0.4 & 0.5 & 0.4 & 0.3 & 0.4 & 0.2 & 0.2 & 0.3 & 0.3 & 0.2 \\
\hline Hungary & 1.4 & 1.3 & 1.5 & 1.5 & 1.4 & 1.4 & 1.3 & 1.2 & 1.3 & 1.2 \\
\hline Malta & 0.1 & 0.1 & 0.1 & 0.1 & 0.1 & 0.1 & 0.1 & 0.1 & 0.1 & 0.1 \\
\hline Netherlands & 12.5 & 12.5 & 12.6 & 12.9 & 13.1 & 13.6 & 13.4 & 13.9 & 14.1 & 14.2 \\
\hline Austria & 1.6 & 1.6 & 1.7 & 1.7 & 1.8 & 1.7 & 1.8 & 1.8 & 1.9 & 1.9 \\
\hline Poland & 1.7 & 2.0 & 2.2 & 2.5 & 2.4 & 2.6 & 2.6 & 2.8 & 2.9 & 3.0 \\
\hline Portugal & 1.0 & 0.9 & 1.0 & 1.0 & 0.9 & 0.9 & 0.9 & 0.9 & 0.9 & 0.9 \\
\hline Romania & 1.0 & 1.1 & 1.0 & 1.1 & 0.8 & 0.8 & 0.9 & 0.8 & 0.8 & 0.9 \\
\hline Slovenia & 0.2 & 0.2 & 0.3 & 0.4 & 0.4 & 0.4 & 0.4 & 0.4 & 0.4 & 0.5 \\
\hline Slovakia & 0.5 & 0.6 & 0.8 & 0.9 & 0.8 & 0.9 & 0.9 & 0.9 & 0.9 & 0.9 \\
\hline Finland & 1.3 & 1.5 & 1.5 & 1.5 & 1.2 & 1.2 & 1.3 & 1.2 & 1.2 & 1.1 \\
\hline Sweden & 2.2 & 2.3 & 2.2 & 2.2 & 2.2 & 2.4 & 2.3 & 2.3 & 2.2 & 2.3 \\
\hline United Kingdom & 15.5 & 15.6 & 14.9 & 13.7 & 15.2 & 14.8 & 14.5 & 15.6 & 14.0 & 14.4 \\
\hline
\end{tabular}

Source: Eurostat 
If we look at the period before and after the global financial crisis, it can be concluded that in relative terms the crisis has not affected to a greater extent the trade flows in the EU. Also, if we look at the founding states and new member states of EMU, it can be concluded that there is no Andrew Rose effect, speaking in relative terms. If we are considering states in the regime of exemptions ${ }^{1}$, in Denmark and Sweden there are not any changes, while in Great Britain slight decline in imports was recorded from $15.5 \%$ in 2005 to $14.4 \%$ in 2014.

In order to determine the actual existence of Andrew Rose effect, the import of countries in absolute terms must be considered, as can be seen in Table 2. In absolute terms, it is evident that the impact of the global financial crisis in 2009 reduced the trade for about $30 \%$. In the reporting period, state regime of exemptions have increased imports by $20 \%$, while Sweden increased imports by $25 \%$. EMU countries that joined the EU in 20042, in the period 2005-2014 increased imports by $100 \%$, except Cyprus.

Table 2

Import of the EMU Countries and EU countries in the Regime of Exemptions, in millions of euro

\begin{tabular}{lllllllllll} 
GEO/TIME & 2005 & 2006 & 2007 & 2008 & 2009 & 2010 & 2011 & 2012 & 2013 & 2014 \\
\hline Estonia & 8.230 & 10.711 & 11.439 & 10.896 & 7.270 & 9.268 & 12.543 & 13.848 & 13.684 & 13.735 \\
Cyprus & 5.077 & 5.518 & 6.286 & 7.237 & 5.617 & 6.464 & 6.234 & 5.678 & 4.754 & 5.075 \\
Latvia & 6.991 & 9.191 & 11.180 & 10.975 & 7.034 & 8.819 & 11.703 & 13.409 & 13.451 & 13.212 \\
Lithuania & 12.498 & 15.429 & 17.813 & 21.144 & 13.123 & 17.653 & 22.826 & 24.882 & 26.208 & 26.531 \\
Malta & 2.988 & 3.430 & 3.503 & 3.604 & 3.210 & 3.818 & 4.520 & 5.135 & 4.606 & 4.883 \\
Slovenia & 16.346 & 19.227 & 23.027 & 25.180 & 19.004 & 22.700 & 25.522 & 24.934 & 25.129 & 25.656 \\
Slovakia & 27.851 & 35.828 & 44.229 & 50.253 & 39.898 & 49.050 & 57.358 & 60.241 & 61.543 & 61.838 \\
Denmark & 60.752 & 68.100 & 71.526 & 74.356 & 59.602 & 62.648 & 68.724 & 71.548 & 72.725 & 74.672 \\
Sweden & 89.781 & 101.583 & 111.803 & 114.565 & 85.945 & 112.352 & 127.174 & 127.649 & 120.931 & 122.376 \\
\hline $\begin{array}{l}\text { United } \\
\text { Kingdom }\end{array}$ & 417.389 & 487.951 & 465.715 & 447.228 & 372.581 & 445.874 & 486.446 & 537.487 & 493.807 & 514.643 \\
\hline
\end{tabular}

Source: Eurostat

\footnotetext{
1 Britain and Denmark are members of the EU and they are in opt-out clause i.e. in the regime of exemptions and they have not joined EMU. Sweden is also in a referendum rejected that as an EU member approaches EMU in 1999.

2 Slovenia became an EMU member in 2007, Cyprus and Malta in 2008, Slovakia in 2009 and Estonia in 2011, Latvia in 2013 and Lithuania in 2014
} 
Table 3

The Share of Exports of the Member Countries in Total EU Exports, in percentage

\begin{tabular}{|c|c|c|c|c|c|c|c|c|c|c|}
\hline GEO/TIME & 2005 & 2006 & 2007 & 2008 & 2009 & 2010 & 2011 & 2012 & 2013 & 2014 \\
\hline Belgium & 5.9 & 6.0 & 6.1 & 5.6 & 5.9 & 6.1 & 6.2 & 6.2 & 6.1 & 6.1 \\
\hline Bulgaria & 0.3 & 0.4 & 0.4 & 0.5 & 0.4 & 0.4 & 0.5 & 0.5 & 0.5 & 0.5 \\
\hline Czech Republic & 0.8 & 0.9 & 1.0 & 1.1 & 1.1 & 1.2 & 1.3 & 1.4 & 1.3 & 1.4 \\
\hline Denmark & 1.9 & 1.8 & 1.8 & 1.8 & 2.0 & 1.8 & 1.8 & 1.8 & 1.7 & 1.8 \\
\hline Germany & 26.4 & 27.6 & 27.3 & 27.3 & 27.4 & 27.8 & 27.6 & 28.0 & 27.0 & 28.0 \\
\hline Estonia & 0.1 & 0.2 & 0.2 & 0.2 & 0.2 & 0.2 & 0.3 & 0.3 & 0.2 & 0.2 \\
\hline Ireland & 3.0 & 2.8 & 2.6 & 2.4 & 2.9 & 2.7 & 2.5 & 2.2 & 2.1 & 2.3 \\
\hline Greece & 0.5 & 0.5 & 0.6 & 0.6 & 0.7 & 0.7 & 0.8 & 0.9 & 0.8 & 0.8 \\
\hline Spain & 4.1 & 4.2 & 4.4 & 4.4 & 4.5 & 4.4 & 4.7 & 5.0 & 5.1 & 5.2 \\
\hline France & 12.9 & 11.8 & 11.4 & 11.5 & 11.9 & 11.4 & 10.8 & 10.8 & 10.2 & 10.2 \\
\hline Croatia & 0.2 & 0.3 & 0.3 & 0.3 & 0.3 & 0.3 & 0.2 & 0.2 & 0.2 & 0.2 \\
\hline Italy & 10.9 & 11.0 & 11.3 & 11.4 & 11.1 & 10.5 & 10.5 & 10.6 & 10.4 & 10.6 \\
\hline Cyprus & 0.0 & 0.0 & 0.0 & 0.0 & 0.0 & 0.0 & 0.0 & 0.0 & 0.0 & 0.0 \\
\hline Latvia & 0.1 & 0.1 & 0.1 & 0.2 & 0.2 & 0.2 & 0.2 & 0.2 & 0.2 & 0.2 \\
\hline Lithuania & 0.3 & 0.4 & 0.4 & 0.5 & 0.4 & 0.5 & 0.5 & 0.5 & 0.6 & 0.6 \\
\hline Luxembourg & 0.2 & 0.2 & 0.2 & 0.2 & 0.2 & 0.2 & 0.2 & 0.2 & 0.2 & 0.1 \\
\hline Hungary & 0.9 & 1.0 & 1.1 & 1.1 & 1.1 & 1.1 & 1.2 & 1.1 & 1.0 & 1.0 \\
\hline Malta & 0.1 & 0.1 & 0.1 & 0.1 & 0.1 & 0.1 & 0.1 & 0.1 & 0.1 & 0.1 \\
\hline Netherlands & 6.2 & 6.6 & 7.1 & 6.9 & 7.3 & 7.3 & 7.1 & 7.3 & 7.1 & 7.2 \\
\hline Austria & 2.6 & 2.5 & 2.5 & 2.5 & 2.4 & 2.4 & 2.3 & 2.3 & 2.3 & 2.4 \\
\hline Poland & 1.4 & 1.6 & 1.7 & 1.9 & 1.8 & 1.8 & 1.9 & 2.0 & 2.2 & 2.2 \\
\hline Portugal & 0.6 & 0.7 & 0.7 & 0.8 & 0.7 & 0.7 & 0.7 & 0.8 & 0.8 & 0.8 \\
\hline Romania & 0.6 & 0.7 & 0.7 & 0.8 & 0.7 & 0.8 & 0.8 & 0.8 & 0.9 & 0.9 \\
\hline Slovenia & 0.3 & 0.4 & 0.4 & 0.4 & 0.4 & 0.4 & 0.4 & 0.4 & 0.4 & 0.4 \\
\hline Slovakia & 0.3 & 0.4 & 0.4 & 0.5 & 0.5 & 0.6 & 0.5 & 0.6 & 0.6 & 0.6 \\
\hline Finland & 2.2 & 2.3 & 2.3 & 2.2 & 1.8 & 1.8 & 1.6 & 1.6 & 1.4 & 1.4 \\
\hline Sweden & 4.1 & 4.1 & 3.9 & 3.8 & 3.6 & 3.8 & 3.8 & 3.4 & 3.1 & 3.0 \\
\hline United Kingdom & 13.0 & 11.6 & 11.0 & 10.9 & 10.5 & 10.9 & 11.7 & 10.9 & 13.3 & 11.6 \\
\hline
\end{tabular}

Source: Eurostat

Table 4

Export of the EMU Countries and EU Countries in the Regime of Exemptions, in millions of euro

\begin{tabular}{lcccccccccc} 
GEO/TIME & 2005 & 2006 & 2007 & 2008 & 2009 & 2010 & 2011 & 2012 & 2013 & 2014 \\
\hline Estonia & 6.202 & 7.719 & 8.034 & 8.470 & 6.487 & 8.743 & 12.003 & 12.518 & 12.310 & 12.083 \\
\hline Cyprus & 1.177 & 1.062 & 1.017 & 1.110 & 901 & 1.058 & 1.306 & 1.354 & 1.520 & 1.359 \\
Latvia & 4.149 & 4.902 & 6.062 & 6.897 & 5.522 & 7.191 & 9.433 & 10.983 & 10.893 & 10.942 \\
\hline Lithuania & 9.490 & 11.263 & 12.509 & 16.077 & 11.797 & 15.651 & 20.151 & 23.048 & 24.545 & 24.401 \\
Malta & 1.928 & 2.226 & 2.508 & 2.367 & 2.049 & 2.705 & 3.151 & 3.308 & 2.738 & 2.117 \\
Slovenia & 15.471 & 18.501 & 21.964 & 23.204 & 18.768 & 22.026 & 24.968 & 25.033 & 25.614 & 27.190 \\
Slovakia & 25.632 & 33.340 & 42.696 & 48.370 & 40.208 & 48.777 & 57.349 & 62.742 & 64.565 & 65.161 \\
Denmark & 68.420 & 73.716 & 75.280 & 79.496 & 67.382 & 72.747 & 80.362 & 82.090 & 82.901 & 83.424 \\
Sweden & 105.266 & 117.707 & 123.179 & 124.645 & 93.763 & 119.597 & 134.313 & 134.387 & 126.147 & 123.726 \\
\hline United & 314.171 & 359.117 & 322.387 & 321.028 & 254.704 & 313.766 & 363.915 & 367.990 & 407.325 & 380.538 \\
Kingdom & & & & & & & & & & \\
\hline
\end{tabular}

Source: Eurostat 
If we look at all Member States, it can be concluded that trade of EMU and the EU countries increased over the years and the share of trade in GDP of EMU countries is grown. Increasing the share of trade in the total GDP of the EMU, can best be seen in the share of the trade in total GDP of EMU, US, Japan, China and Russia, as is shown in Table 5.

Table 5

The Share of Exports and Imports of Goods and Services as a Percentage of GDP

\begin{tabular}{lrrrrrrrrrrrr} 
& \multicolumn{1}{c}{ Imports } \\
\cline { 2 - 14 } & 2007 & 2008 & 2009 & 2010 & 2011 & 2012 & 2007 & 2008 & 2009 & 2010 & 2011 & 2012 \\
Euro area & 40.1 & 41.1 & 35.5 & 40.0 & 42.9 & 43.2 & 41.5 & 42.0 & 36.9 & 41.3 & 44.3 & 45.8 \\
Japan & 16.1 & 17.5 & 12.3 & 14.0 & 16.1 & 16.6 & 17.7 & 17.7 & 12.7 & 15.2 & 15.1 & 14.7 \\
$\begin{array}{l}\text { United } \\
\text { States }\end{array}$ & 16.4 & 17.4 & 13.7 & 15.8 & 17.2 & 16.9 & 11.5 & 12.5 & 11.0 & 12.3 & 13.5 & 13.5 \\
China & 29.6 & 27.3 & 22.3 & 25.6 & 25.9 & 24.5 & 38.4 & 35.0 & 26.7 & 29.4 & 28.5 & 27.3 \\
$\begin{array}{l}\text { Russian } \\
\text { Federation }\end{array}$ & 21.5 & 22.1 & 20.5 & 21.1 & 21.8 & 22.1 & 30.2 & 31.3 & 27.9 & 29.2 & 30.4 & 29.4 \\
\hline
\end{tabular}

Source: OECD

The share of exports and imports of goods and services as percentage of GDP is higher than most developed countries of the world. Despite the impact of the crisis of 2009, exports to EMU accounts for half of GDP, while in all other highly developed countries, despite lower growth, that share is much smaller and consists of up to $30 \%$ in China and Russia and does not exceed $20 \%$ in Japan and United States.

\section{Data and Methodology}

Of great benefit in this research is the application of analytical research methods, which allow individual identification of significant factors affecting the increase in trade. Its application enables us to further define and study the effects of trade in the member countries of the European Monetary Union. The paper was used and the comparative method. The purpose of its use was to contribute to the comparison of the same phenomenon in different countries, or to point to an increase in the level of trade in the countries of the European Monetary Union. In order to facilitate the grouping, sorting and comparison of quantitative research results was used statistical methods. Analysis of the economic parameters will be based on the application of the statistical trend. The data used for this study were obtained from official data of Eurostat, the European Commission and The Organisation for Economic Co-operation and Development (OECD)

\section{Results}

If we observe the share of exports of the Member States in the period before and after the global financial crisis, it can be concluded as with the share of imports that in relative terms the crisis has not affected to a greater extent the trade flows in the EU. Also, if we look at the founding states and new member states of EMU, it can be concluded that there is no Rose effect, speaking in relative terms. In the case of countries in the regime of exemptions there is a drop in the share of exports in the reporting period.

But speaking in absolute terms, the situation is quite different and it can be said that Andrew Rose effect exists. Despite a reduction in exports by more than $30 \%$ in 
2009 due to the impact of the global financial crisis, during the period 2005-2014 we increased the state exporting to an absolute amount of $100 \%$ to $270 \%$, ie. the states have increased the trade for more than three times. If there is an impact of monetary integration on increasing international trade of Member States it can be seen in the case of countries in the regime of exemptions. While Lithuania and Slovakia have increased exports by $270 \%$ in the same period, Denmark has increased its exports by $22 \%$, UK $21 \%$ and Sweden $17 \%$, which is 5 times less than the state with the lowest export growth in the EMU.

\section{Discussion}

Increasing trade between Member States, which form a monetary union, is the result of previously meeting and realized the benefits of monetary integration. In order to increase trade between countries, first need to reduce the transaction costs of exchange, to increase price transparency to eliminate the uncertainty of exchange rate fluctuations, which means that the increase in trade is secondary benefit of monetary integration.

Of great importance of this research is the review of the position of exports and imports in the period from 2005 to 2014 , in order to assess the level of their fulfillment. The period from 2005 to 2015 is used for showing the impact of monetary integration on increasing trade before and after the global financial crisis, and 2005 was chosen because of the large expansion of the European Union in 2004.

\section{Conclusion}

Looking at the eurozone and compared with the other two leading world economies, it can be concluded that it is relatively open. In 2012, the combined value of exports and imports of goods and services accounted for $44 \%$ of GDP, while in the United States and Japan, the share was 15\%. It can be concluded that the EMU open zone and that this openness increases from year to year. The greatest impact of openness exists within EMU countries, which have increased mutual trade and financial flows.

An analysis of impact of monetary integration on international trade flows is necessary in absolute terms. In absolute amounts, European monetary integration has contributed to an increase in exports to the Member States to $270 \%$ in the tenyear period. This is the result of expanding markets, volume and exchange of goods and services. In monetary union it comes to expansion of market integration between the countries, which contribute to the reduction of national borders in choosing economic activity, which is produced closer to consumers regardless of the country from which the company originates. Price transparency, elimination of transaction costs and the elimination of exchange rate uncertainties contribute to the increase of international trade in countries of the monetary union. Finally, it can be concluded that the hypothesis that the monetary union will increase the volume of trade is true, and that the Andrew Rose effect is largely met.

\section{References}

1. Baldwin, R., Wyplosz, C. (2010), „Ekonomija evropskih integracija" [Economy of European Integration], treće izdanje, Data status, Beograd.

2. Chang, M. (2009), "Monetary integration in the European Union", Palgrave Macmmilan, New York.

3. Engel, C., Rose, A. (2002), "Currency Unions and International Integration", Journal of Money, Credit, and Banking, Vol. 34 No. 4. 
4. ECB (2008), "Monthly Bulletin 10th Anniversary of the ECB", Frankfurt.

5. Frankel, J., Rose A. (2002), "An estimate of the effect of common currencies on trade and income", The Quarterly Journal of Economics, pp. 437-466.

6. Furtula, S., Marković, D. (2010), Monetarni sistem Evropske unije, Ekonomski fakultet, Kragujevac.

7. Furtula, S., Stanišić, N., Lojanica, N. (2013), „Dissimilarity in achieving the Convergence Criteria in EMU ex post and ex ante Global Financial Crisis", Actual Problems of Economics, No 9(147), National Academy of Management, Kyiv, Ukraine.

8. Gern, K.J. et al. (2004), "European Monetary Integration after EU Enlargement", Institut fur Weltwirtschaft, Kiel.

9. Ingham, B. (2004), "International Economics: a European Focus", Prentice Hall, Harlou.

10. Kenen, P., Meade, E. (2008), "Regional monetary integration“, Cambridge University Press, New York.

11. Mundell, R. (1961), "A Theory of Optimum Currency Areas", The American Economic Review, LI, No. 4, pp. 509-517.

12. Rose A. (2000), "One Money, one market: the effect of common currencies on trade", Economic Policy: A European Forum, No. 30.

13. Rose A., Spiegel M.M. (2011), „The Olympic effect”, The Economic Journal, Vol. 121, pp. 652-677

14. Stanley, T.D., Rose, A. (2005), "A meta-analysis of the effect of common currencies on international trade", Journal of economic surveys, Vol. 19 No. 3, Blackwell Publishing Ltd., pp. 347-365.

15. Tomann, H. (2007), „Monetary Integration in Europe“, Palgrave Macmillan, New York.

\section{About the authors}

PhD Srđan Šapić is Associate Professor at the Faculty of Economics, University of Kragujevac, Serbia, where he defended his PhD thesis in scientific field of of Business Economics and Management. He teaches the subjects International business and International marketing (undergraduate studies), Intercultural marketing (master studies) and Management of international business (doctoral studies) at the Faculty of Economics, University of Kragujevac. His research interests include international business and international marketing. Author can be contacted at ssapic@kg.ac.rs

PhD Srđan Furtula is Assistant Professor at the Faculty of Economics, University of Kragujevac, Serbia, where he defended his PhD thesis in scientific field of Finance, Financial Institutions and Insurance. He teaches the subject Monetary Finance (undergraduate studies), and Monetary system of the European Union (master studies) at the Faculty of Economics, University of Kragujevac. His research interests include finance, monetary policy, and monetary integration. Author can be contacted at furtulas@kg.ac.rs 